\title{
Hydrology and Hydraulic Analysis of Nasiri Flash Flood Disaster Event on the $1^{\text {st }}$ August 2012
}

\author{
Imam Syarif Hidayatulloh \\ Directorate General of Water Resource, Ministry of Public Works and Housing, Jakarta, INDONESIA \\ penafsir_mimpi@yahoo.com \\ Adam Pamudji Rahardjo \\ Department of Civil and Environmental Engineering, Universitas Gadjah Mada, Yogyakarta, INDONESIA \\ adam.pamudji.r@gmail.com \\ Bambang Agus Kironoto \\ Department of Civil and Environmental Engineering, Universitas Gadjah Mada, Yogyakarta, INDONESIA \\ kironoto@tsipil.ugm.ac.id
}

\begin{abstract}
Nasiri lays in the Luhu village, Huamual district, West Seram Regency, Maluku province. Nasiri experienced in flash flood on August $1^{\text {st }}, 2012$ which had never happened before. There was no rainfall station and water level recorder at that time. It is rather difficult to find out the cause and yet Nasiri River was only 8 meters wide. The research started with identifying base flow, soil characteristics, learning flood video record, routing the river reach, finding the nearest rainfall station, and also interviewing some peoples there. Field data area was complemented with satellite radars. AutoCAD 2007, IFAS 2.0.1.2, Geostudio 2004, ArcGIS 10.2, HEC-HMS 4.2.1, and HEC-RAS 5.0.3 were used to perform simulations of the natural river with and without precipitation calibration, and also with and without landslide dam in the river. HEC-RAS was subject to perform 2 (two) dimensional flood routing. The result was fairly satisfying. Nasiri watershed was experiencing in flash flood caused by 2 (two) landslide dams which collapsed in 2 (two) different times. The first landslide dam was 7.55 meters high which collapsed at 09:52 $(\mathrm{UTC}+9)$ with $83.58 \mathrm{~m} 3 / \mathrm{s}$ of peak discharge. The second landslide dam was 8.91 meters high which collapsed at 14:24 (UTC+9) with $54.16 \mathrm{~m}^{3} / \mathrm{s}$ of peak discharge.
\end{abstract}

Keywords: Nasiri, flood, landslide dam, two-dimensional routing.

\section{FLOODS AND LANDSLIDES}

Floods and landslides are the most frequent disasters in Indonesia. Based on data and information from National Disaster Management Agency (BNPB, 2017), recorded 1,481 times of disaster from January to July 2017. Flood and landslide disaster has contributed $3.17 \%$ of total disaster incidents with locations spread throughout Indonesia. It caused 19 people died and disappeared, 37 people were injured, 163 houses were severely damaged, 4,438 houses were slightly damaged, and 105,768 people suffered and displaced. Given the significant number of victims, research on these disasters is indispensable as a mitigation effort.

\section{RESEARCH METHOD}

\subsection{Nasiri Location}

Nasiri is located on a peninsula that has a land width of $\pm 5 \mathrm{~km}$. Geographically, Nasiri lies at $3^{\circ} 20^{\prime} 25.80^{\prime \prime}-$ $3^{\circ} 20^{\prime} 37.18^{\prime \prime} \mathrm{S}$ and $127^{\circ} 56^{\prime} 14.22^{\prime \prime}-127^{\circ} 56^{\prime} 27.62^{\prime \prime} \mathrm{E}$.
Nasiri is a small village with the length of east-west \pm 500 meters and long north-south \pm 300 meters. Hamlet of Lirang in the north, the hamlet of Talaga Kambelu in the west, and to the east by the hills (Figure 1).

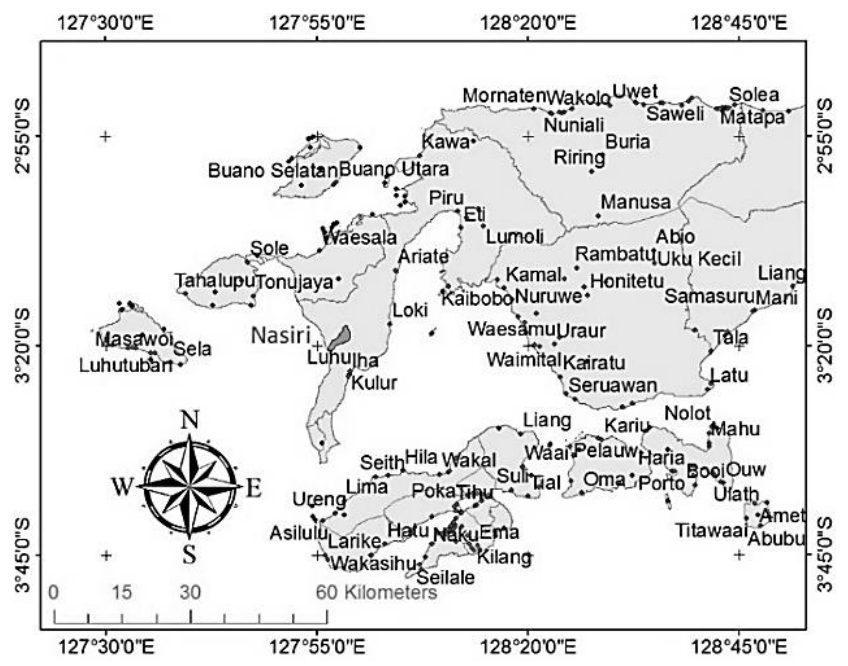

Figure 1. Nasiri’s location. 
Nasiri was flash flooded on August $1^{\text {st, }}$ 2012. It was the only flood that ever happened, and yet this paper was going to analyze the flash flood event chronologically.

\subsection{Research Flow Chart}

Because there were so many variables in this research, a simple flow chart was drawn for analysis as shown in Figure 2.

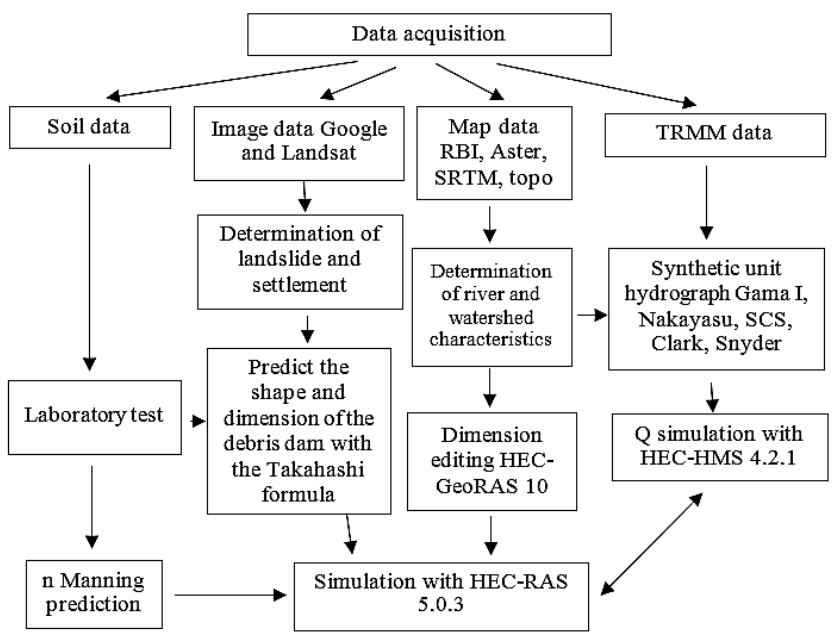

Figure 2. Research flowchart.

\subsection{Soil Investigation}

Some samples of soil were tested in the Universitas Gadjah Mada laboratory. Those samples were taken from several places in Nasiri as shown in Figure 3. Sieve analysis showed that the soil contains $70 \%$ of sand. The most appropriate Soil Conservation ServiceCurve Number (SCS-CN) classification is B (after Nearing et al., (1996)).

The composite value for CN B in Nasiri is 59.457. The result from the laboratory is listed in Table 1.

Table 1. Manning's $n$ value prediction

\begin{tabular}{lll}
\hline Method & Sample 1 & Sample 2 \\
\hline Strickler (1923) & 0.046 & 0.046 \\
MPM (1948) & 0.054 & 0.057 \\
Julien (2002) & $0.074 ; 0.058 ;$ & $0.073 ; 0.062 ;$ \\
& 0.054 & 0.056 \\
\hline
\end{tabular}

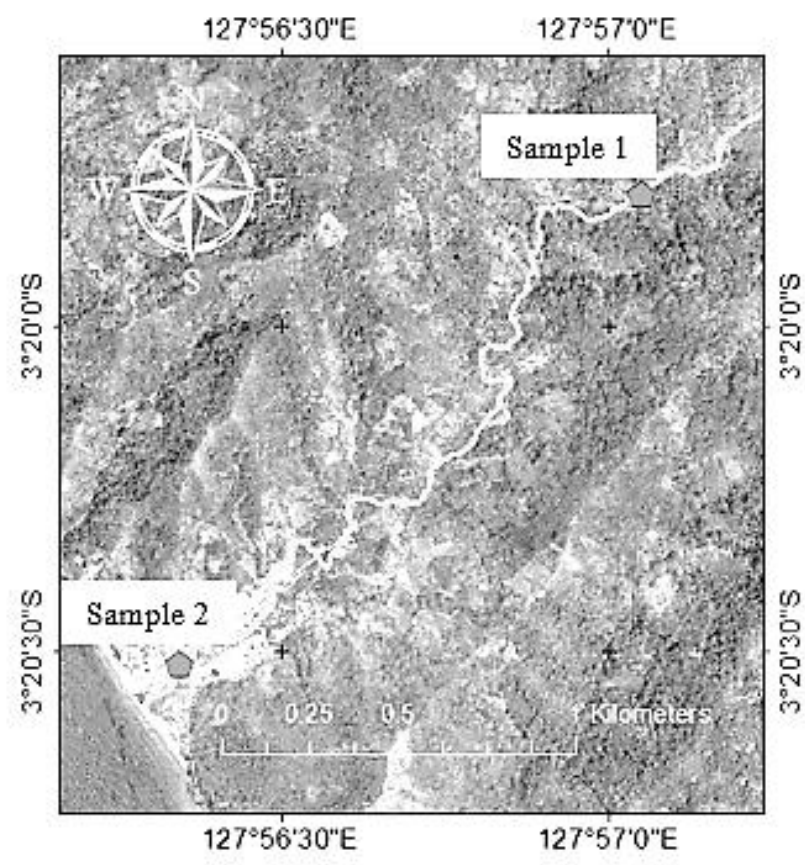

Figure 3. Soil samples data acquisition place.

\subsection{Satellite Images}

Google satellites recorded an avalanche and river flow path in the upstream of Nasiri. It lied $\pm 1.5 \mathrm{~km}$ from the people settlements at the altitude of +53 meters above sea level (MASL). Figure 4 shows the evidence of an avalanche on the river bank, while Figure 5 presents 3 (three) locations that allegedly occurred landslide. Landsat images could not display clearly because of its $30 \times 30$ meters resolution.

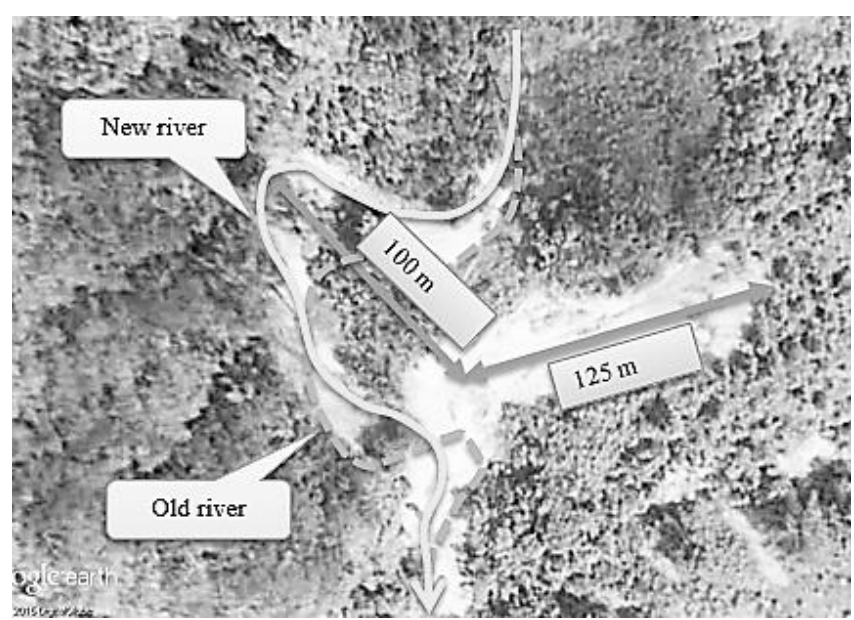

Figure 4. Image from the Google satellite on October 8th, 2012. 


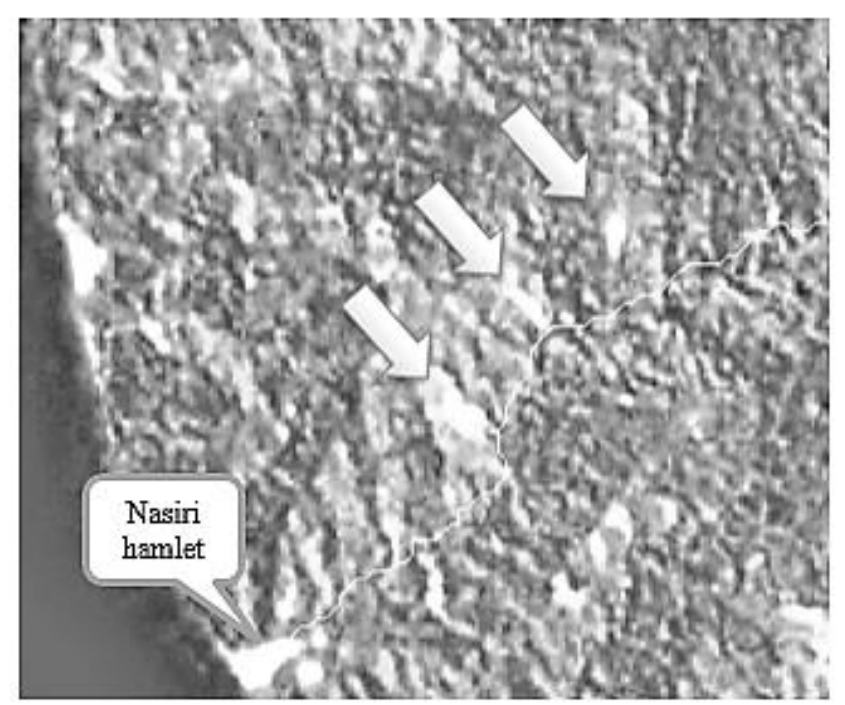

Figure 5. Image from ArcGIS online imagery.

\section{DIGITAL SURFACE MODELS (DSM) AND DIGITAL TERRAIN MODELS (DTM) COMPARISON}

ASTER (1 arc-second), SRTM (1 arc-second), and RBI (Indonesian Topographical Map with 25 meters of contour interval) were compared to the ground survey mapping (see Figure 6, Figure 7 and Figure 8). By means of Nash-Sutcliffe (1970) index, the comparison result is shown in Table 2. Choosing the GPS-TOPO map was more accurate for river reach, while SRTM was useful for watershed elevation. ArcHydro version 2 was used to create watershed delineation and river reach confluence. To improve the accuracy of river reach elevations and population settlements, the authors added 2,500 points based on documentation and tracing on the ground to obtain Digital Elevation Models (DEM) with a resolution of 1 x 1 meter.

Table 2. Nash-Sutcliffe index of Digital Surface Models (DSM)/Digital Terrain Models (DTM) elevation

\begin{tabular}{llll}
\hline ASTER & SRTM & RBI & GPS-TOPO \\
\hline-1.618 & 0.703 & 0.322 & 0.938 \\
\hline
\end{tabular}

Table 3. Watershed characteristics comparison

\begin{tabular}{llll} 
Parameter & ASTER & SRTM & RBI \\
Area $\left(\mathrm{km}^{2}\right)$ & 10.523 & 10.551 & 10.492 \\
River length $(\mathrm{km})$ & 7.965 & 8.201 & 7.902 \\
River slope $(\mathrm{m} / \mathrm{m})$ & 0.092 & 0.089 & 0.105 \\
River confluence & 20 & 21 & 45 \\
Min. elev. (m) & 0 & 8 & 3.694 \\
Max. elev. (m) & 916 & 931 & 903.673 \\
\hline
\end{tabular}

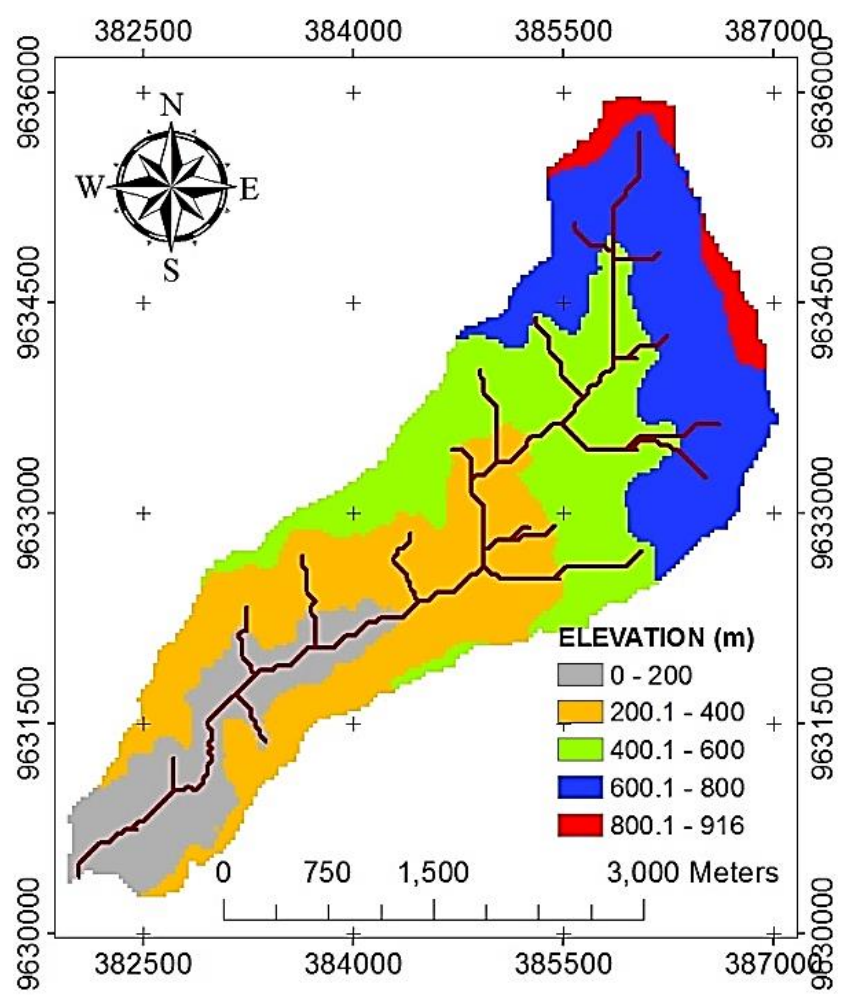

Figure 6. ASTER watershed (2011)

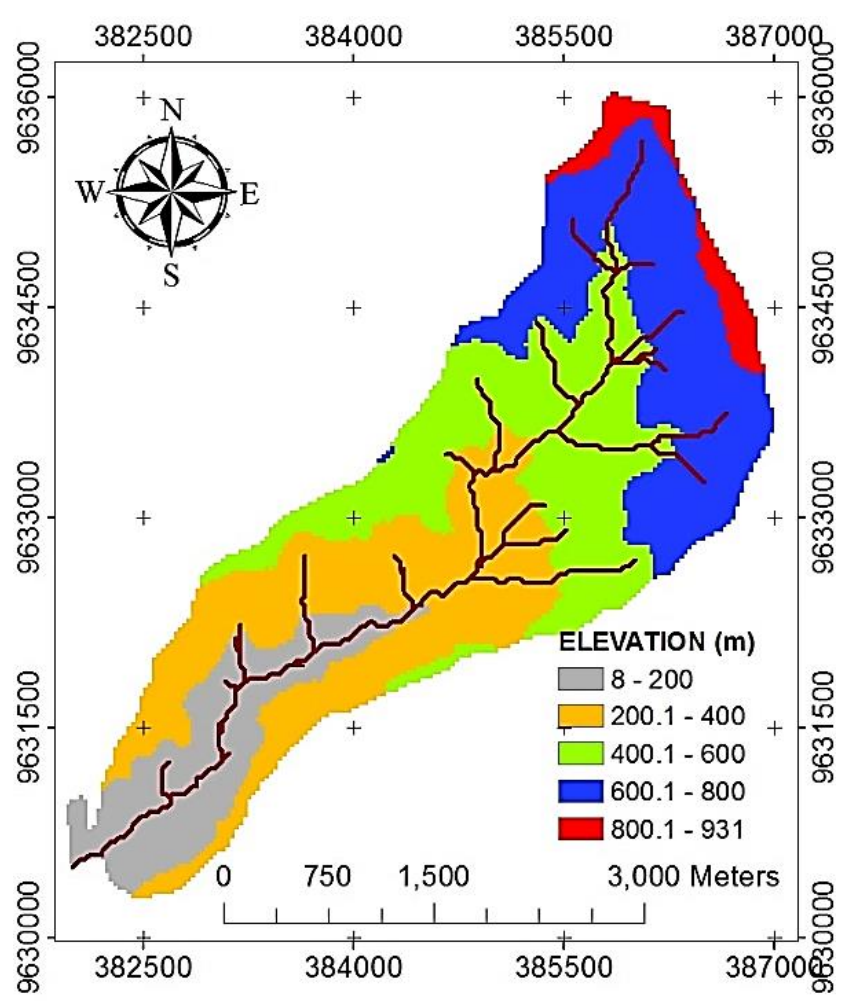

Figure 7. SRTM watershed (2014) 


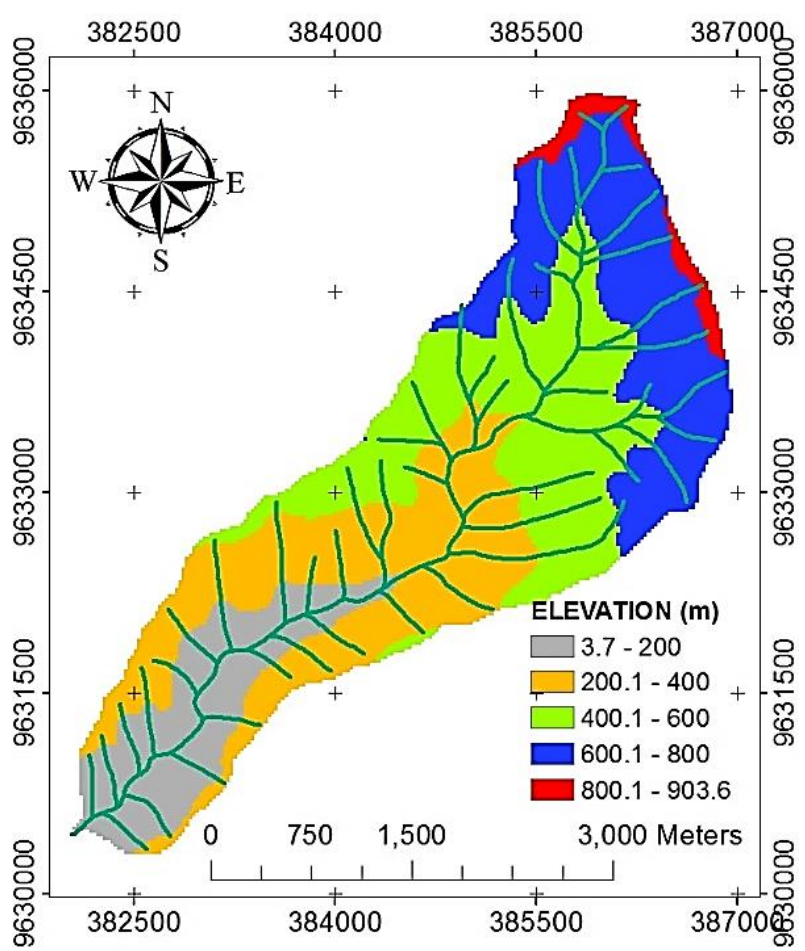

Figure 8. RBI watershed (2009).

\section{RESULTS AND DISCUSSIONS}

\subsection{Landslide Dam Dimension Prediction}

The dimensions of landslide dams were predicted with an empirical model of Takahashi (2007), as presented by Equation 1 to Equation 4 and Figure 9.

$$
\begin{aligned}
& L_{B}=\frac{W}{\cos \theta}+\frac{V \cos \theta}{2 B W} K \\
& L_{T}=\frac{W}{\cos \theta}-\frac{V \cos \theta}{2 B W} K \\
& K=\frac{\cos \theta}{\tan (\varphi+\theta)}+\sin \theta+\frac{\sin \left(90^{\circ}+\varphi\right)}{\sin (\varphi-\theta)}
\end{aligned}
$$

$$
D_{\max }=\frac{2 V}{B\left(L_{B}+L_{T}\right)}
$$

(a)
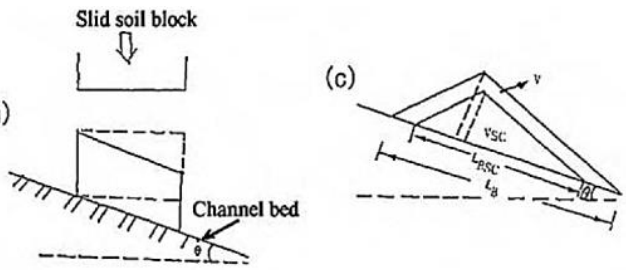

(b)
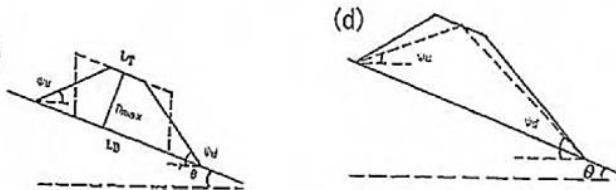

Figure 9. Landslide dam transformation (Takahashi, 2007)
Preliminary prediction of landslide dam dimension is presented in Table 4. The value will be tested in the HEC-RAS simulation, while the prediction of landslide location that forms the natural dam is presented in Figure 10.

Table 4. Landslide dam dimension prediction

\begin{tabular}{llll}
\hline \multirow{2}{*}{ Parameters } & \multicolumn{2}{l}{ Dimension } \\
\cline { 2 - 4 } & Up (3) & $\begin{array}{l}\text { Middle } \\
(2)\end{array}$ & Bottom (1) \\
\hline$L_{T}(\mathrm{~m})$ & 24.60 & 0.02 & 27.26 \\
$L_{B}(\mathrm{~m})$ & 75.53 & 26.70 & 49.75 \\
$D_{\max }(\mathrm{m})$ & 16.98 & 8.96 & 7.55 \\
$\theta\left({ }^{\circ}\right)$ & 0.53 & 0.69 & 0.86 \\
$\psi_{u}\left({ }^{\circ}\right)$ & -0.10 & -0.09 & -0.56 \\
$\psi_{d}\left({ }^{\circ}\right)$ & 0.95 & 1.27 & 1.15 \\
Elev. (MASL) & +101.87 & +78.53 & +53.23 \\
\hline
\end{tabular}

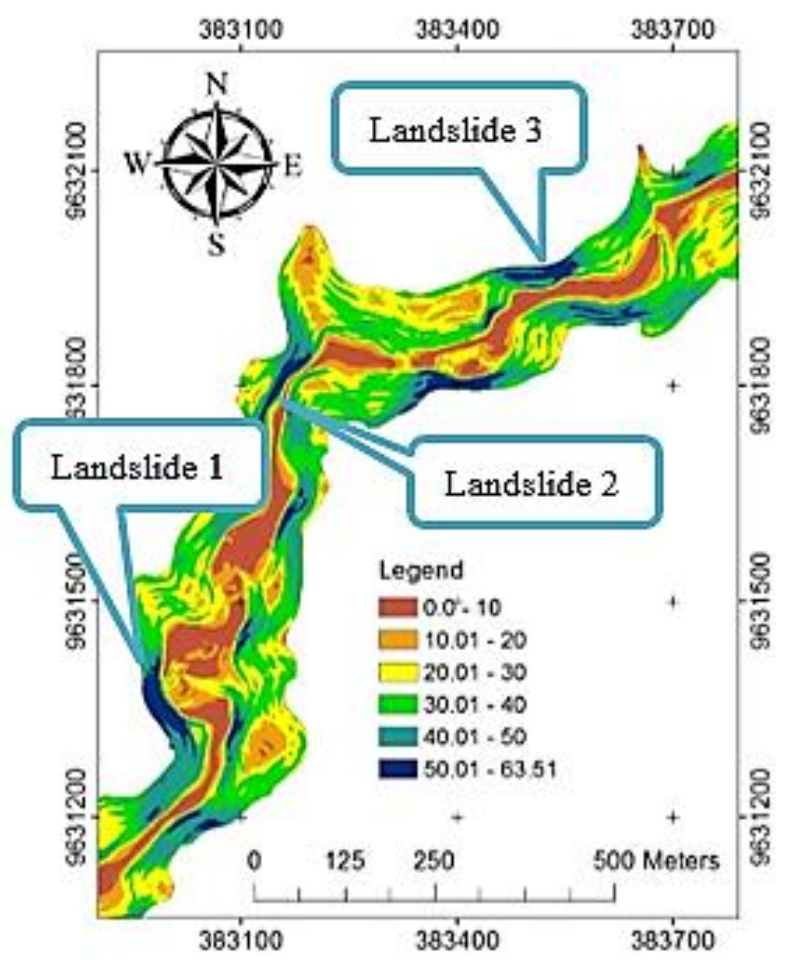

Figure 10. Slope $\left(^{\circ}\right)$ and landslide dam location.

\subsection{Landslide Dam Stability Factor}

The dimensions of landslide dams were tested for stability with GEOSTUDIO 2004. Material models were using Mohr-Coulomb (Parry, 2004). The results are displayed in Figure 11, Figure 12, Figure 13, and Table 5. 


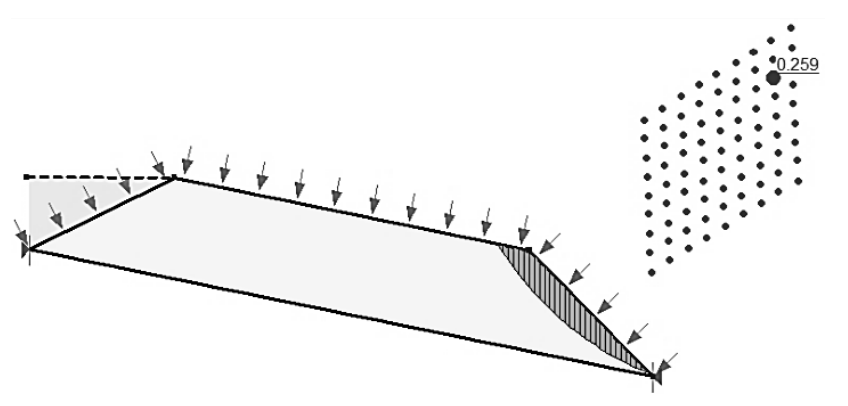

Figure 11. Landslide 1 model.

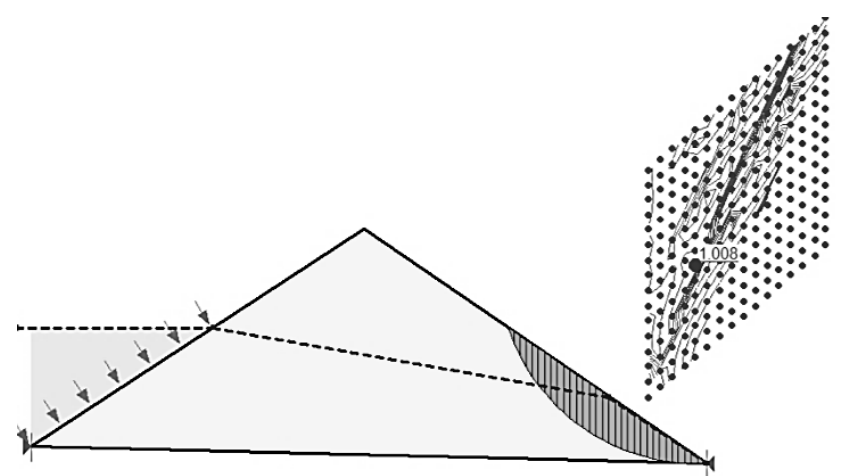

Figure 12. Landslide 2 model.

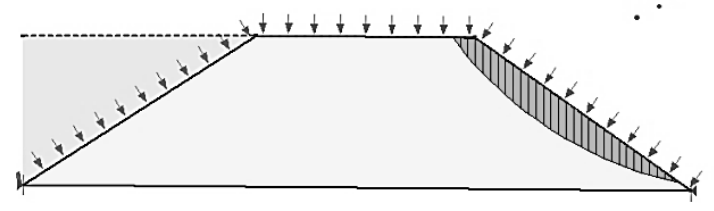

Figure 13. Landslide 3 model.

Table 5. Failure type of each landslide model

\begin{tabular}{llll}
\hline Landslide & 1 & 2 & 3 \\
\hline Elev. invert $(\mathrm{m})$ & +53.23 & +78.53 & +101.87 \\
Shape & trapezoidal & triangle & trapezoidal \\
Failure type & overtopping & piping & overtopping \\
Elev. failure (m) & +60.78 & +85.95 & +123.89 \\
\hline
\end{tabular}

\subsection{Nasri's Resident Documentary}

A resident was documenting the flood events with his phone video camera. It was a very rough video, but it could illustrate the magnitude of the flood (Hidayatulloh, 2017). From Figure 14 it appeared that flood flow was very fast $( \pm 5.4 \mathrm{~m} / \mathrm{s})$ and muddy, swept away trees, and have destroyed many houses. Predicted discharge is $54.16 \mathrm{~m}^{3} / \mathrm{s}$ at $14: 38 \mathrm{PM}(\mathrm{UTC}+9)$.

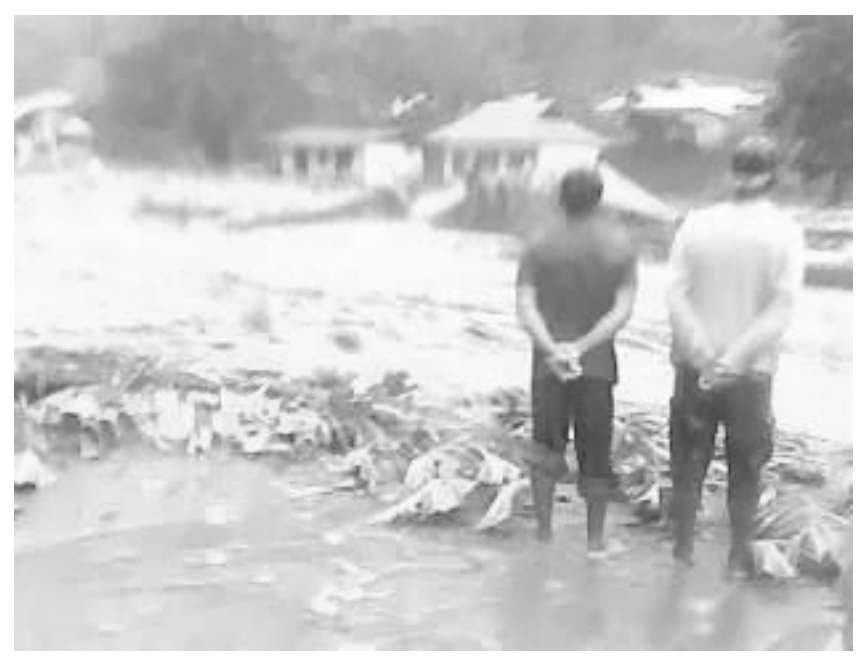

Figure 14. A captured image from video recording during the flood (Hidayatulloh, 2017).

Flood modeling which was done with HEC-RAS and HEC-HMS would be adjusted with oral information obtained on 13-20 July 2014 from several Nasiri residents. Resume of oral information is shown in Table 6.

Table 6. Nasiri resident oral information

\begin{tabular}{ll}
\hline Date & Information \\
\hline $7 / 27-$ & There was no landslide in river reach. \\
$7 / 29 / 2012$ & \\
$7 / 31 / 2012$ & $\begin{array}{l}\text { The rain started in the afternoon and lasted } \\
\text { continuously until the evening. }\end{array}$ \\
8/1/2012 & $\begin{array}{l}\text { The rain still lasts until night. There was a } \\
\text { flash flood at 10:00 AM (UTC+9). The } \\
\text { turbid flood waters carry trunks of trees, } \\
\text { mud, and rocks. The riverbed changed } \\
\text { direction and crashed 61 buildings to } \\
\text { shreds. The flood waters receded for } \\
\text { several hours but rose again in the } \\
\text { afternoon. Toward late at night, the river } \\
\text { water has subsided to normal. } \\
\text { The weather was sunny and reportedly no } \\
\text { rain. The river water gradually changes its } \\
\text { turbidity level to normal again. }\end{array}$ \\
\hline
\end{tabular}

\subsection{Precipitation Data}

The most popular satellite precipitation data in Indonesia is Tropical Rainfall Measuring Mission (TRMM) 3B42RT version 7. In Maluku Province, the monthly data correlation was 0.78 and looks underestimate when compared to ground rainfall data (Mamenun, et al., 2014). In Lohiatala, a rainfall station which lies $\pm 43 \mathrm{~km}$ from Nasiri, TRMM was still underestimated at main rainfall months (July-August). TRMM recorded only $88 \%$ of total precipitation amount. While in Patimura, a rainfall station which lies $\pm 44 \mathrm{~km}$ from Nasiri, TRMM has a good monthly correlation of 0.95 . 


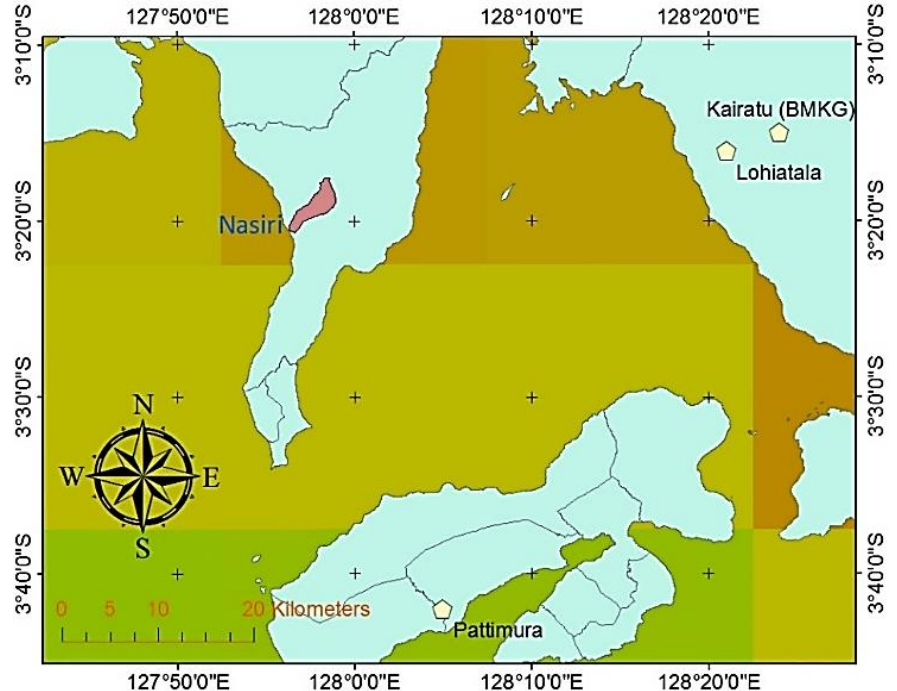

Figure 15. Tropical Rainfall Measuring Mission (TRMM) grid compares to rainfall station position.

Table 7. Tropical Rainfall Measuring Mission (TRMM) precipitation data

\begin{tabular}{lll}
\hline $\begin{array}{l}\text { Date } \\
\text { (WIT) }\end{array}$ & $\begin{array}{l}\text { TRMM 3B42RT v.7 } \\
(\mathrm{mm})\end{array}$ & $\begin{array}{l}\text { Calibrated } \\
(\mathrm{mm})\end{array}$ \\
\hline 19-Jul-12 & 1.3363 & 1.5056 \\
20-Jul-12 & 117.3647 & 132.2320 \\
21-Jul-12 & 1.0137 & 1.1421 \\
22-Jul-12 & 8.3404 & 9.3969 \\
23-Jul-12 & 0.0000 & 0.0000 \\
24-Jul-12 & 0.0461 & 0.0519 \\
25-Jul-12 & 0.0000 & 0.0000 \\
26-Jul-12 & 0.0000 & 0.0000 \\
27-Jul-12 & 0.0000 & 0.0000 \\
28-Jul-12 & 0.4147 & 0.4672 \\
29-Jul-12 & 0.0000 & 0.0000 \\
30-Jul-12 & 1.0137 & 1.1421 \\
31-Jul-12 & 55.9406 & 63.0269 \\
1-Aug-12 & 199.3790 & 224.6355 \\
2-Aug-12 & 12.1467 & 13.6854 \\
3-Aug-12 & 0.0000 & 0.0000 \\
4-Aug-12 & 0.0000 & 0.0000 \\
\hline
\end{tabular}

According to the rainfall data in Patimura station, the highest rainfall was recorded at $263 \mathrm{~mm}$ on June $28^{\text {th }}$, 2007. The highest rainfall in the Lohiatala station was $372 \mathrm{~mm}$ on January $2^{\text {nd }}, 2009$. The highest rain sequence ever in the Nasiri basin, based on the 19982014 data, can be seen in Table 8 .

The precipitation that occurred on August $1^{\text {st }}, 2012$ was in the fourth rank. While on August $4^{\text {th }}, 2010$, there was no flood in Nasiri. In contrary, on June $8^{\text {th }}, 2012$ there was no flood recorded. The results implied that rainfall was not the main factor as the cause of flood incident on August 1 ${ }^{\text {st }}, 2012$.

Table 8. Highest precipitation in Nasiri (TRMM)

\begin{tabular}{lll}
\hline No & Date (UTC) & Intensity (mm/hour) \\
\hline 1 & $2010: 08: 04$ & 226 \\
2 & $2010: 06: 16$ & 183 \\
3 & $2011: 06: 05$ & 174 \\
4 & $2012: 08: 01$ & 141 \\
5 & $2012: 06: 08$ & 137 \\
6 & $2008: 08: 04$ & 137 \\
7 & $2011: 05: 19$ & 127 \\
8 & $2004: 02: 18$ & 119 \\
9 & $1999: 07: 03$ & 113 \\
10 & $2012: 07: 31$ & 113 \\
\hline
\end{tabular}

\subsection{Natural River Flow Hydrograph}

Five synthetic unit hydrographs (SUHs) were compared to view the peak flood at 10:00 AM on August $1^{\text {st }}, 2012$. HEC-HMS simulation result without landslide dam is shown in Table 9 and Figure 16.

Table 9. Peak flow from synthetic unit hydrographs (SUHs)

\begin{tabular}{lll}
\hline SUH & Peak flow $\left(\mathrm{m}^{3} / \mathrm{s}\right)$ & $\begin{array}{l}\text { Time } \\
(\mathrm{UTC}+9)\end{array}$ \\
\hline Gama I (Sri Harto, 1985) & 36.587 & $09: 24$ \\
Nakayasu (1951) & 40.206 & $09: 00$ \\
SCS (Snider, 1972) & 42.032 & $09: 20$ \\
Snyder (1938) & 43.192 & $09: 04$ \\
Clark (1945) & 43.273 & $09: 06$ \\
\hline
\end{tabular}

\section{Hourly Hydrograph at August 1, 2012}

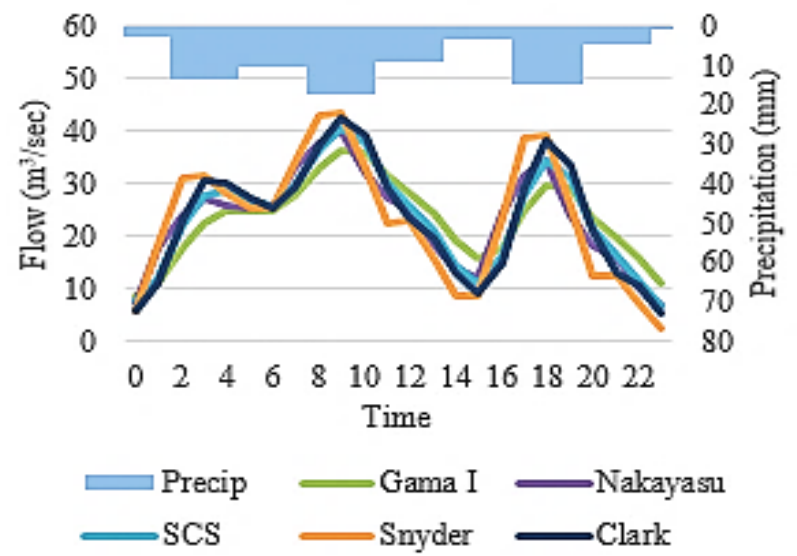

Figure 16. Hourly hydrographs on August 1st, 2012

There are differences between SUHs in Figure 16 and Table 6. Peak flow was occurred at 09:00 till 09:24, while Nasiri's residents said that the flood hit at 10:00. Approximated peak flow was more than $60 \mathrm{~m}^{3} / \mathrm{s}$, while Figure 16 shows different results. There must be two 
landslides in the river upstream. The first was before 10:00 AM and the second was before 14:38 PM.

\subsection{Calibrating Manning Roughness Coefficients}

Several $n$ values from Table 1 were simulated in HECRAS 5.0.3. Full momentum equations were applied in this case as listed in Equation 5 and Equation 6 (Brunner, 2016).

$$
\begin{aligned}
& \frac{\partial u}{\partial t}+u \frac{\partial u}{\partial x}+v \frac{\partial u}{\partial y}=-g \frac{\partial H}{\partial x}+v_{t}\left(\frac{\partial^{2} u}{\partial x^{2}}+\frac{\partial^{2} u}{\partial y^{2}}\right)-c_{f} u+f v \\
& \frac{\partial v}{\partial t}+u \frac{\partial v}{\partial x}+v \frac{\partial u}{\partial y}=-g \frac{\partial H}{\partial y}+v_{t}\left(\frac{\partial^{2} v}{\partial x^{2}}+\frac{\partial^{2} v}{\partial y^{2}}\right)-c_{f} v+f u
\end{aligned}
$$

(6)

Table 10. Index of Nash-Sutcliffe $(\eta)$ for Flood Plain

\begin{tabular}{llllll}
\hline$n$ Manning & 0.046 & 0.056 & 0.057 & 0.062 & 0.073 \\
\hline Index $(\boldsymbol{\eta})$ & 0.454 & 0.977 & 0.995 & 0.943 & 0.638 \\
\hline
\end{tabular}

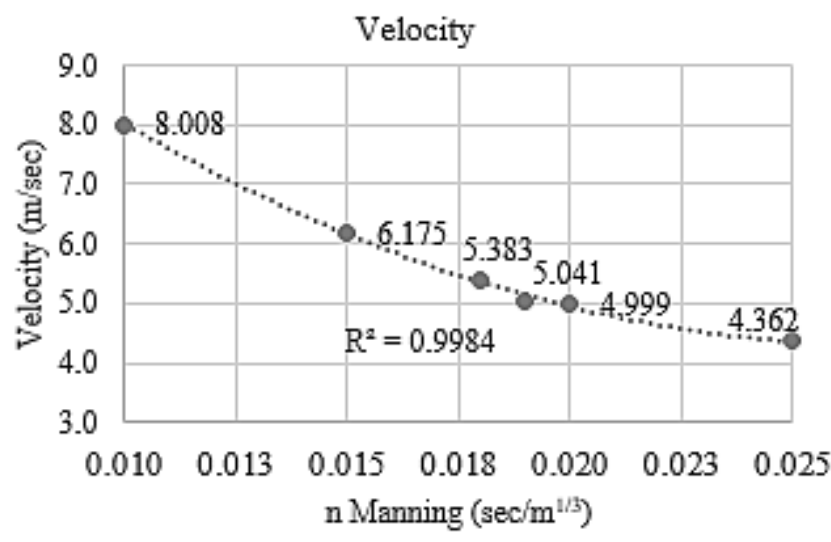

From some of the Manning $n$ values, it can be calculated the ideal value for settlements and river channel by rating curves (Figure 17). From Table 10, the value of $n=0.057$ (MPM, 1948) resulted in the best and the maximum debit at 10:00 (UTC+9), i.e. 83.58 $\mathrm{m}^{3} / \mathrm{s}$. As for the Manning $n$ value of the river channel corresponding to the information in Section 9 was 0.018 , which resulted in a velocity of $5.4 \mathrm{~m} / \mathrm{s}$.

\subsection{Compatibility of Runoff Volume}

Flood analysis from July $19^{\text {th }}, 2012$ to August $4^{\text {th }}, 2012$ obtained a predicted volume of 4,538,304 $\mathrm{m}^{3}$. The calculated results from several Ia-CN values are listed in Table 11. The ideal value of Ia-CN is listed in Table 12.

Table 11. Ideal value of Ia-CN for Nasiri

\begin{tabular}{llll}
\hline $\mathrm{Ia}$ & 0.05 & 0.10 & 0.15 \\
\hline $\mathrm{CN}$ & 65.838 & 67.428 & 68.831 \\
\hline
\end{tabular}

\subsection{Time of the First Landslide}

Four locations were set as calibration points (Figure 18). The four calibration points had the value of flow depth at peak flood as shown in Table 13. The entire HEC-RAS simulation was performed over 36,800 cells measuring $3 \times 3$ meters and at 0.3 second calculation time interval.

Table 12. Flow depth at peak flood

\begin{tabular}{lll}
\hline No & Location & Depth \\
\hline 1 & School & 1.0 meter \\
2 & House 1 & 0.8 meter \\
3 & House 2 & 0.7 meter \\
4 & Mosque & 0.5 meter \\
\hline
\end{tabular}

Figure 17. Rating curve for velocity.

Table 13. Runoff volume comparison from standard and calibrated precipitation $\left(\times 1000 \mathrm{~m}^{3}\right)$

\begin{tabular}{lllllllll}
\hline CN & Ia $=0.05$ & \multicolumn{3}{c}{ Ia $=0.10$} & \multicolumn{1}{c}{ Ia $=0.15$} & \multicolumn{3}{c}{0.20} \\
\cline { 2 - 9 } & standard & calibrated & standard & calibrated & standard & calibrated & standard & calibrated \\
\hline 45 & 3203.8 & 3626.9 & 3076.1 & 3494.9 & 2950.0 & 3364.1 & 2825.6 & 3234.6 \\
50 & 3421.8 & 3866.2 & 3311.5 & 3752.9 & 3202.1 & 3640.3 & 3093.7 & 3528.5 \\
55 & 3629.7 & 4091.9 & 3535.5 & 3995.6 & 3441.7 & 3899.7 & 3348.5 & 3804.3 \\
60 & 3828.0 & 4304.9 & 3748.6 & 4224.1 & 3669.3 & 4143.5 & 3590.4 & 4063.1 \\
65 & 4017.5 & 4506.3 & 3951.5 & 4439.5 & 3885.6 & 4372.8 & 3757.4 & 4242.9 \\
70 & 4198.6 & 4697.1 & 4144.9 & 4642.9 & 4091.3 & 4588.8 & 4037.8 & 4534.8 \\
\hline
\end{tabular}




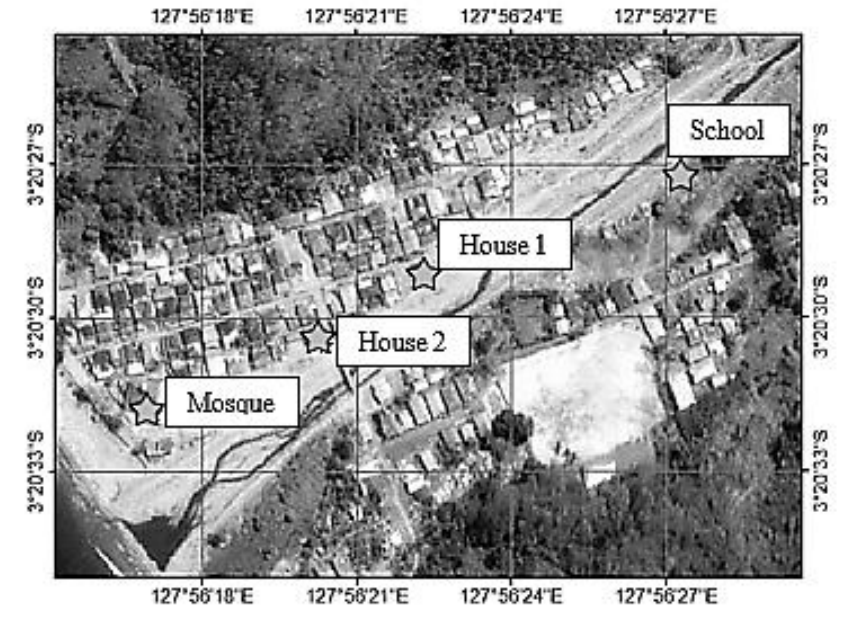

Figure 18. Calibration points.

According to Table 14 and Table 15, it can be concluded that there was an avalanche in the river channel at an elevation of +53.23 MASL as high as 7.55 meters at 09:40 and began to collapse at 09:52. The most appropriate breach formula is Von Thun and Gillette (1990) (see also Figure 19).

\subsection{Time for the Second Landslide}

Analog by way of the first landslide was calculated, then the calculation for flood at 14:38 was also performed. The central landslide as high as 8.96 meters at the +78.53 MASL elevation was simulated in HECRAS. From the HEC-HMS simulation without a landslide dam, the Nasiri River only supplies $16-20$ $\mathrm{m}^{3} / \mathrm{s}$ of discharge at 14:00 - 15:00. In contrast to the lower landslides seen quite clearly from Google Earth imagery, the central landslide was not clearly visible from satellite imagery. So it takes several times experiment of the dimension of the middle landslide. The experiment of the landslide dimension should refer to the potential avalanche area seen from ArcGIS imagery online imagery.

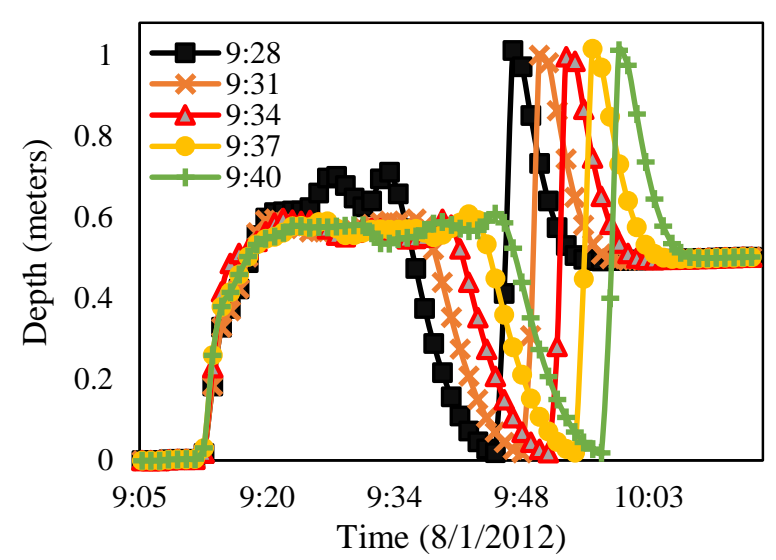

Figure 19. Flow depth at school caused by landslide dam (1) from 09:28 to 09:40 with Von Thun and Gillette (1990) breach formula.

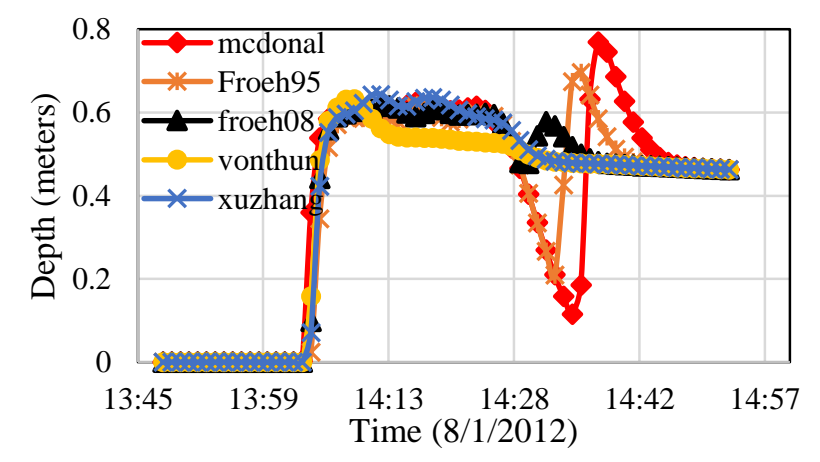

Figure 20. Flow depth at school caused by landslide dam (2).

Table 14. Flow depth caused by landslide dam (1) (meter)

\begin{tabular}{lllllll}
\hline Formula & Time & School & House 1 & House 2 & Mosque & Velocity (m/sec) \\
\hline McDonald and Monopolis (1984) & $9: 33$ & 0.870 & 0.848 & 0.583 & 0.332 & 3.075 \\
Froehlich (1995) & $9: 37$ & 0.930 & 0.903 & 0.603 & 0.349 & 3.214 \\
Froehlich (2008) & $9: 37$ & 0.965 & 0.899 & 0.598 & 0.353 & 3.273 \\
Von Thun and Gillette (1990) & $9: 40$ & 1.001 & 0.925 & 0.649 & 0.362 & 3.269 \\
Xu \& Zhang (2009) & $9: 37$ & 0.921 & 0.895 & 0.575 & 0.349 & 3.175 \\
\hline
\end{tabular}

Table 15. Index $\eta$ from landslide dam (1)

\begin{tabular}{llllll}
\hline Formula & McDonald (1984) & Froehlich (1995) & Froehlich (2008) & Von Thun (1990) & Xu \& Zhang (2009) \\
\hline Index $\eta$ & 0.531 & 0.631 & 0.670 & 0.714 & 0.587 \\
\hline
\end{tabular}


Table 16. Dimension prediction of landslide dam (2)

\begin{tabular}{llllll} 
Parameters & 1 & 2 & 3 & 4 & 5 \\
\hline $\mathrm{L}_{\mathrm{T}}(\mathrm{m})$ & 0.02 & 0.09 & 0.23 & 0.36 & 0.50 \\
$\mathrm{~L}_{\mathrm{B}}(\mathrm{m})$ & 26.70 & 26.61 & 26.48 & 26.34 & 26.20 \\
$\mathrm{D}_{\max }(\mathrm{m})$ & 8.96 & 8.91 & 8.82 & 8.73 & 8.64 \\
$\theta\left(^{\circ}\right)$ & 0.69 & 0.69 & 0.69 & 0.69 & 0.69 \\
$\psi_{u}\left({ }^{\circ}\right)$ & -0.09 & -0.09 & -0.09 & -0.10 & -0.10 \\
$\psi_{d}\left({ }^{\circ}\right)$ & 1.27 & 1.27 & 1.27 & 1.27 & 1.27 \\
River invert & +78.5 & +78.5 & +78.5 & +78.5 & +78.5 \\
$(\mathrm{~m})$ & & & & & \\
\hline
\end{tabular}

Table 18 shows that there was an avalanche in the river channel at +78.53 MASL elevation as high as 8.91 meters at 14:19 and began to collapse at 14:24. The flood hazard map from the HEC-RAS simulation could be seen in Figure 21.
Table 17. Flood depth from the second avalanche

\begin{tabular}{ccccccc}
\hline $\begin{array}{c}\text { Heig } \\
\text { ht } \\
(\mathrm{m})\end{array}$ & Time & School & $\begin{array}{c}\text { House } \\
1\end{array}$ & $\begin{array}{c}\text { House } \\
2\end{array}$ & $\begin{array}{c}\text { Mosq } \\
\text { ue }\end{array}$ & $\begin{array}{c}\text { Veloc } \\
\text { ity } \\
(\mathrm{m} / \mathrm{s})\end{array}$ \\
\hline 8.96 & $14: 18$ & 0.768 & 0.790 & 0.516 & 0.313 & 2.509 \\
8.91 & $14: 19$ & 0.753 & 0.748 & 0.475 & 0.302 & 3.048 \\
8.82 & $14: 19$ & 0.741 & 0.746 & 0.463 & 0.296 & 3.025 \\
8.73 & $14: 19$ & 0.741 & 0.744 & 0.463 & 0.296 & 3.025 \\
8.64 & $14: 19$ & 0.728 & 0.737 & 0.454 & 0.292 & 3.006 \\
\hline
\end{tabular}

Table 18. Index $\eta$ for landslide dam (2)

\begin{tabular}{llllll}
\hline Height (meters) & 8.96 & 8.91 & 8.82 & 8.73 & 8.64 \\
\hline Index $\eta$ & 0.970 & 0.999 & 0.998 & 0.998 & 0.993 \\
\hline
\end{tabular}

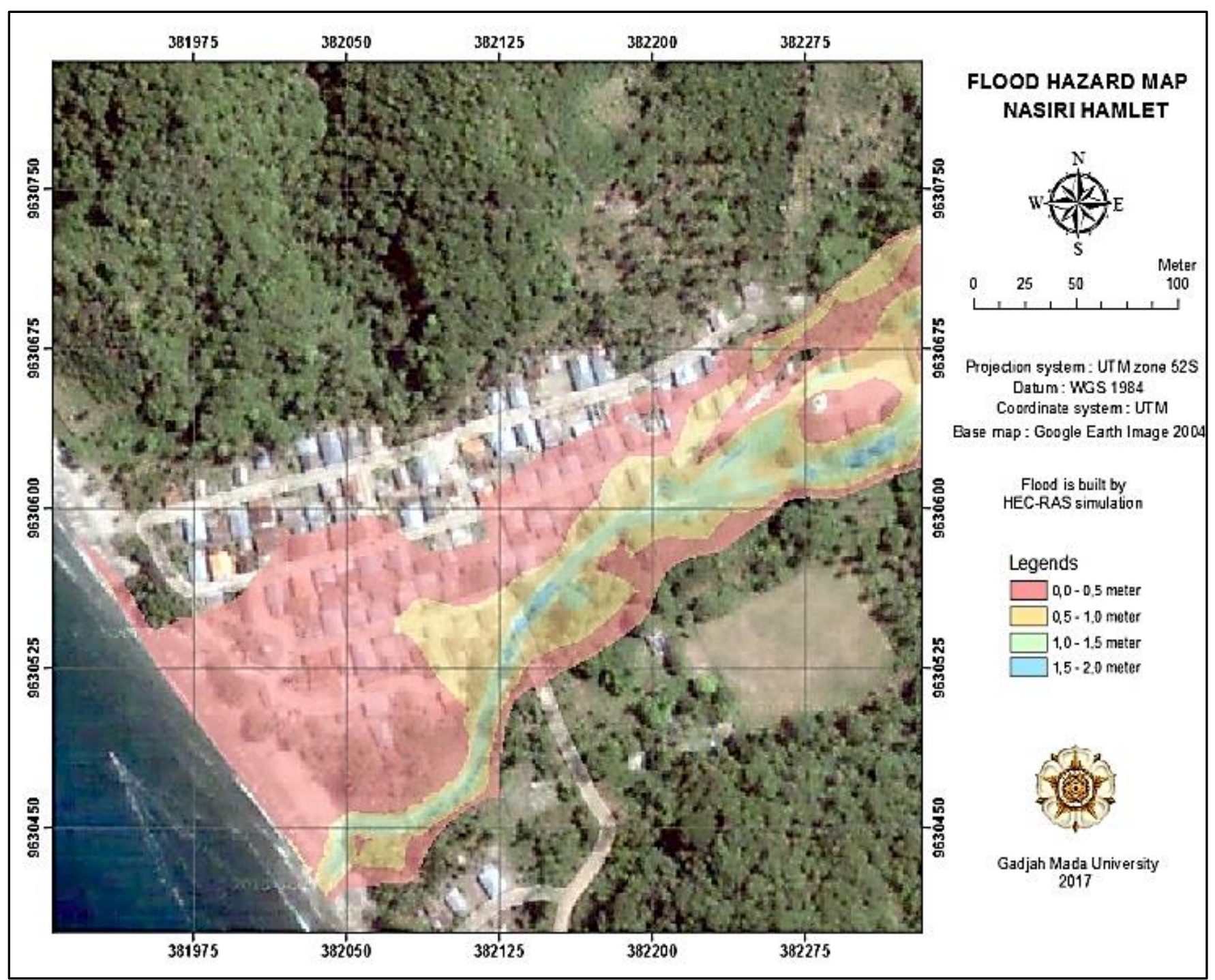

Figure 21. Flood hazard map at Nasiri. 


\section{CONCLUSIONS}

Only 46 houses, or about $47 \%$ of the total settlements area, were free from floods. The chronological flow of flood events in Nasiri watershed is as follows.

July $31^{\text {st }}, 2012$ at $17: 00$, it started to rain in the afternoon.

August 1 ${ }^{\text {st }}, 2012$

09:40 First landslide dam formed at +53.23 MASL elevation as high as 7.55 meters.

09:52 First landslide dam collapsed.

10:00 First flood came into the settlements and destroyed 61 houses. Peak discharge was 83.58 $\mathrm{m}^{3} / \mathrm{sec}$.

14:19 Second landslide dam formed at +78.53 MASL elevation as high as 8.91 meters.

14:24 Second landslide dam collapsed.

14:38 Second flood came into the settlements. Peak discharge is $54.16 \mathrm{~m}^{3} / \mathrm{sec}$.

21:00 Rain stopped and the flow began to recede.

\section{ACKNOWLEDGMENTS}

The authors would like to thank Universitas Gadjah Mada for funding this project as a part of capacity development on natural disaster risk management for communities in small islands.

\section{REFERENCES}

\section{BNPB, 2017.}

Available at: http://dibi.bnpb.go.id

[Online]

Brunner, G. W., 2016. HEC-RAS River Analysis System Hydraulic Reference Manual, Davis: US Army Corps of Engineers Hydrologic Engineering Center.

Froehlich, D. C., 1995. Embankment Dam Breach Parameters Revisited. ASCE: Water Resources Engineering Proceedings.

Froehlich, D. C., 2008. Embankment Dam Breach Parameters and Their Uncertainties. J. Hydraul. Eng, pp. 1708-1721.
Hidayatulloh, I. S., 2017. Flood Modelling in Nasiri, Huamual District, West Seram Regency, Yogyakarta: Master Thesis, Faculty of Engineering, Universitas Gadjah Mada.

Julien, P. Y., 2002. River Mechanics. Cambridge University Press.

Mamenun, Pawitan, H. \& Sophaheluwakan, A., 2014. Validasi dan Koreksi Data Satelit TRMM Pada Tiga Pola Hujan di Indonesia. Puslitbang BMKG: Jurnal Meteorologi dan Geofisika, 15(1).

McDonald, T. C. \& Langridge-Monopolis, J., 1984. Breaching Characteristics of Dam Failures. J. Hydraul. Eng, Issue 110, pp. 567-586.

Nash, J. \& Sutcliffe, J., 1970. River flow forecasting through conceptual models. Part 1: Discussion of Principles. Journal of Hydrology, Issue 10, pp. 282290.

Nearing, M., Liu, B., Risse, L. \& Zhang, X., 1996. Curve numbers and Green-Ampt effective hydraulic conductivities. Water Resources Bulletin, February.32(1).

Parry, R., 2004. Mohr Circles, Stress Paths and Geotechnics. London: Spon Press.

Strickler, 1923. Contributions to the Question of a Velocity Formula and Roughness Data for Streams, Channels and Closed Pipelines (translated by Thomas Roesgen and William R. Brownlie). Pasadena: California Institute of Technology.

Takahashi, T., 2007. Debris Flow: Mechanics, Prediction, and Counter measures. Leiden: CRC Press/Balkema.

Xu, Y. \& Zhang, L., 2009. Breaching Parameters for Earth and Rockfill Dams. J. Geotech Geoenviron. Eng, Issue 135, pp. 1957-1970. 